\title{
Retrograde diagenesis, a widespread process on a regional scale
}

\author{
F. NIETO ${ }^{1}$, M. Pilar MATA ${ }^{2}$, B. BAUluZ ${ }^{3}$, G. GIORGETTI ${ }^{4}$, P. ÁRKAI $^{5}$ \\ AND D. R. PEACOR
}

\begin{abstract}
${ }^{1}$ Instituto Andaluz de Ciencias de la Tierra and Departamento de Mineralogía y Petrología, University of GranadaCSIC, 18002 Granada, Spain, ${ }^{2}$ Departamento de Geología, University of Cádiz, Campus Río San Pedro, 11510 Puerto Real, Cádiz, Spain, ${ }^{3}$ Departamento de Ciencias de la Tierra, University of Zaragoza, 50009 Zaragoza, Spain, ${ }^{4}$ Dipartimento di Science della Terra, University of Siena, Siena, Italy, ${ }^{5}$ Laboratory for Geochemical Research, Hungarian Academy of Sciences, H-1112 Budapest, Budä̈rsi u't 45, Hungary, and ${ }^{6}$ Department of Geological Sciences, The University of Michigan. Ann Arbor, MI-48109, US
\end{abstract}

(Received 18 March 2004; revised 19 July 2004)

\begin{abstract}
ABS TRACT: Pelitic and basic rocks occurring within prograde sequences in Portugal, Spain and Hungary have been studied by X-ray powder diffraction (XRD), scanning electron microscopy (SEM) and transmission electron microscopy (TEM). The minerals formed in typical prograde reactions define the general sequences, but smectite, chlorite-smectite (corrensite) and/or berthierine were found to have replaced chlorite, whereas kaolinite and mixed-layer illite-smectite replaced illite-muscovite. Alteration occurred under conditions normally associated with diagenesis, subsequent to regional metamorphism, and we therefore refer to such processes with the term "retrograde diagenesis". In the cases studied and in other cited examples, reactions occurred on a regional basis via pervasive fluids under open-system conditions inferred to be related to tectonic stress. The observed alterations could generally not be inferred from XRD data, although the presence of pure smectite in sediments other than bentonite is suggestive of retrograde relations, especially where other minerals are consistent with a higher grade of diagenesis. Retrograde diagenesis is readily observed through imaging of textures by TEM, however. Textural features show that retrograde reactions are more common than generally assumed, and that care should be used in interpreting geological events where appropriate textural relations are not seen.
\end{abstract}

KEYwORDS: retrograde, diagenesis, XRD, TEM, SEM, illite-smectite, chlorite-smectite, regional metamorphism.

The term "retrograde diagenesis" was coined by Nieto \& Peacor (1993) to designate fluid-mediated retrograde processes occurring under diagenetic conditions. Retrograde metamorphic reactions are commonly observed as overprints on peak-metamorphic mineral assemblages. More importantly, metamorphism may be followed by later, independent low-grade metamorphic events which overprint or even destroy evidence of older, higher-grade assemblages. Superposition of reactions typical of

* E-mail: nieto@goliat.ugr.es

DOI: $10.1180 / 0009855054010158$ lower-grade on older, higher-grade mineral assemblages is rarely observed in rocks subject to diagenesis and low-grade metamorphism. Nevertheless, recent studies have documented retrograde reactions resulting from alteration by lowtemperature fluids overprinting prograde mineral assemblages (Merriman \& Peacor, 1999).

Such retrograde reactions, detected by TEM, may be restricted to local environments, or may affect whole sequences (Table 1). Jiang et al. (1990a) described regionally developed illite that reacted locally with fault-related fluids to form interstratified illite-smectite (I-S). Jiang et al. (1992) described berthierine replacing chlorite under non- 


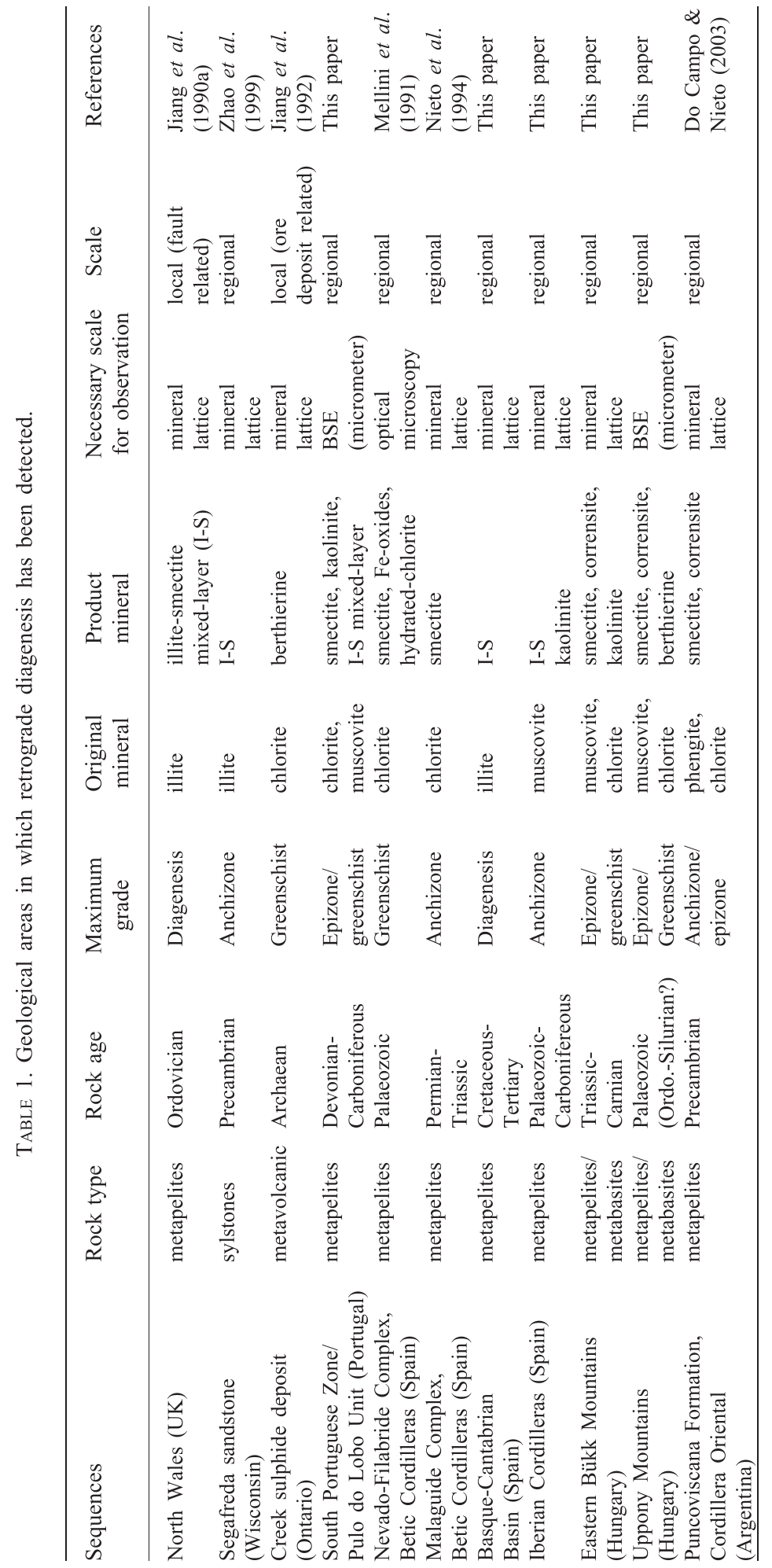


equilibrium conditions in the heterogeneous local environment of a sulphide deposit.

Low-grade schists of the Nevado-Filabride Complex, Spain, provide a more general example of superposition of lower-grade minerals on those of higher grade. A mineral with optical characteristics resembling those of biotite was characterized by Mellini et al. (1991) as smectite or "hydrated chlorite". They postulated "uplift of the Veleta rocks, due to thinning of the upper tectonic units and the Veleta nappe itself by erosion and/or extensional post-metamorphic processes". Nieto et al. (1994) identified smectite as commonly occurring in slates of the Malaguide Complex, Spain, at grades well above that at which smectite normally occurs. The dioctahedral smectite was shown by TEM to have replaced prograde trioctahedral chlorite, subsequent to peak metamorphism.

Zhao et al. (1999) showed by TEM that I-S and minor smectite formed through reaction of muscovite with fluids on a regional scale in the Precambrian Freda Formation (Wisconsin and Michigan), where XRD data demonstrated a normal increase in illite component with increasing depth, as for a normal prograde sequence.

Corrensite was identified by XRD (Do Campo, 1999) and recognized by TEM as layers interstratified in chlorite packets in several slates of the Puncoviscana Formation (Cordillera Oriental, NW Argentina). Smectite also occurs in packets clearly discordant with phengite and chlorite or in pores of the rock (Do Campo \& Nieto, 2003). Judging from measurements of the Kübler index, metamorphic grade ranges between medium anchizone and epizone. Biotite has been found in some slates and felsic metavolcanic rocks interbedded in the sedimentary sequence.

All these papers show the superposition of lowergrade minerals on higher-grade assemblages. In this paper we present new examples of retrograde overprinting in varied geological settings (Table 1) which concern regionally developed mineral assemblages, and show that such relations are far more common than generally recognized. The South Portuguese zone is described in greater detail because it represents widespread development of retrograde reactions detectable at both the nanometer and micrometer scales. We describe those relations here, and use the term "retrograde diagenesis" to describe them, in part to emphasize their significance and relation to retrograde metamorphism, but because they occur in the range of temperature normally attributed to diagenesis.

\section{METHODS}

Fresh unweathered samples were selected from previous studies (see below). They were obtained well below the surface, some from boreholes, usually far from fault zones. X-ray diffraction data were obtained to determine modal composition and phyllosilicate characteristics of whole-rock and $<2 \mu \mathrm{m}$ samples.

Sticky wax-backed thin sections were prepared with surfaces normal to bedding or cleavage, and first examined by optical microscopy. Typical areas were removed for scanning electron microscope (SEM) and TEM observations via attached $\mathrm{Al}$ washers, thinned in an ion mill and carbon coated. Scanning electron microscopy observations of ionmilled samples and thin sections were made using an Hitachi S570 instrument. The TEM data were obtained with a Philips CM-12 scanning-transmission electron microscope (STEM). Both the SEM and STEM were fitted with Kevex Quantum solidstate detectors and computer systems, the detector having a boron-composite window permitting analysis of low atomic number elements. The STEM was operated at $120 \mathrm{kV}$ and a beam current of $20 \mu \mathrm{A}$. In order to obtain optimum contrast in I-S ordering, through-focus series of images were obtained from $1000 \AA$ underfocus (approximate Scherzer defocus) to $1000 \AA$ overfocus. However, because initial focus was controlled manually by minimizing contrast, small deviations from exact underfocus or overfocus numbers were inevitable. A camera length of $770 \mathrm{~mm}$ and a selected-area aperture $10 \mu \mathrm{m}$ in diameter were used to obtain selected area electron diffraction (SAED) area. Energy dispersive spectroscopy (EDS) data were processed using Kevex software, with resultant intensity ratios being corrected with k-values determined for wellcharacterized samples, following the methods described by Nieto et al. (1996).

\section{RES ULT S}

South Portuguese zone and Pulo do Lobo Unit (SPZ)

The SPZ consists of a low-grade sequence of Devonian to Carboniferous metapelites alternating 


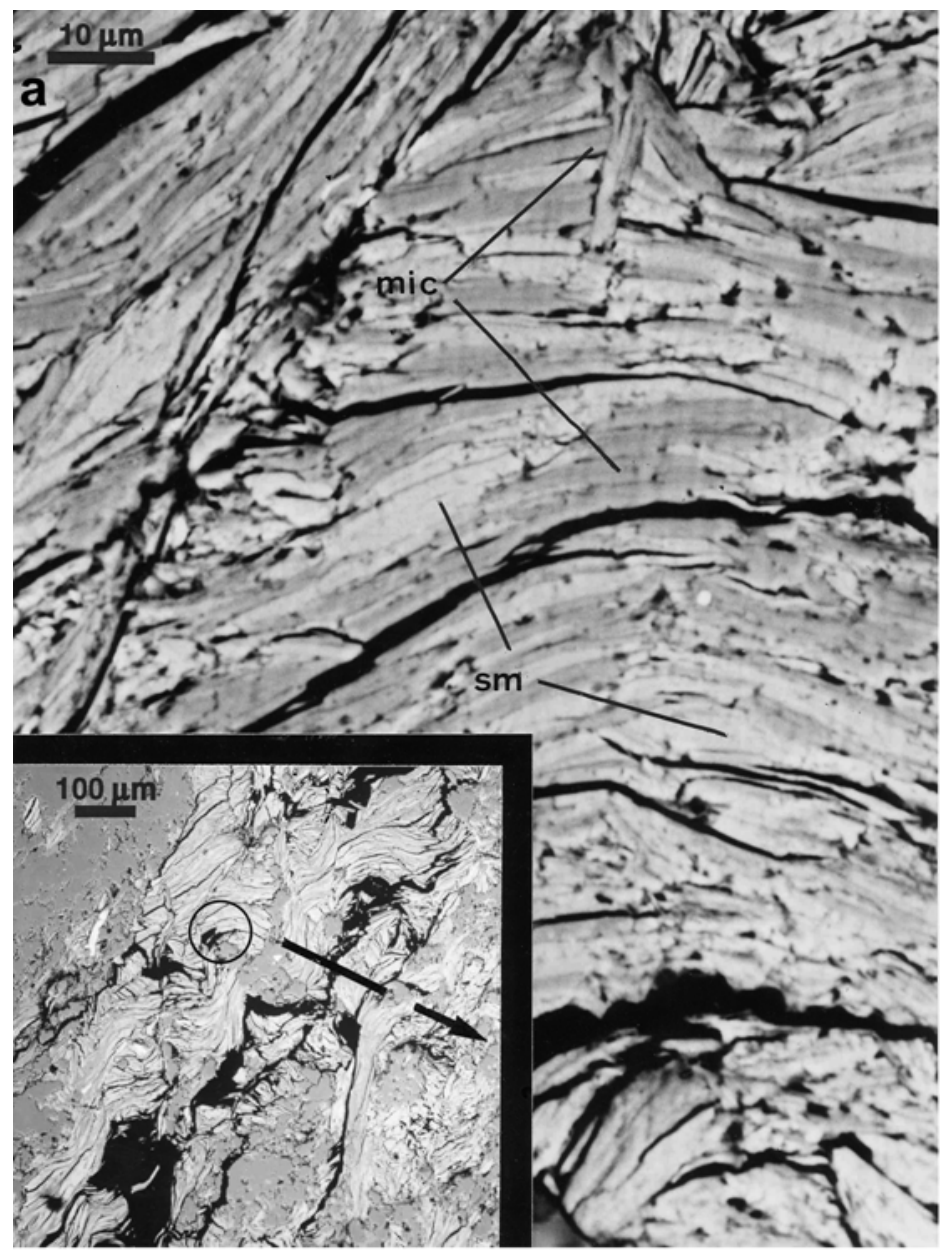

b

mic

$\mathrm{s} \mathbf{m}$

mic 
TABLE 2. Chemical composition (a.p.f.u.) of smectites in sample P $\beta-94$ (Pulo do Lobo Unit).

\begin{tabular}{lcccccccccc}
\hline & Si & ${ }^{\mathrm{IV}} \mathrm{Al}$ & ${ }^{\mathrm{VI}} \mathrm{Al}$ & $\mathrm{Fe}$ & $\mathrm{Mg}$ & $\Sigma$ oct. & $\mathrm{K}$ & $\mathrm{Na}$ & $\mathrm{Ca}$ & $\Sigma$ Int. \\
\hline PB-94 10 & 3.72 & 0.28 & 1.10 & 0.85 & 0.15 & 2.10 & 0.07 & 0.00 & 0.03 & 0.10 \\
PB-94 11 & 3.52 & 0.48 & 1.08 & 0.90 & 0.13 & 2.12 & 0.08 & 0.00 & 0.09 & 0.17 \\
PB-94 23 & 3.74 & 0.26 & 1.20 & 0.51 & 0.35 & 2.06 & 0.27 & 0.15 & 0.01 & 0.43 \\
PB-94 28 & 3.50 & 0.50 & 1.25 & 0.73 & 0.14 & 2.13 & 0.14 & 0.10 & 0.01 & 0.25 \\
PB-94 31 & 3.81 & 0.19 & 1.54 & 0.16 & 0.36 & 2.06 & 0.24 & 0.10 & 0.02 & 0.35 \\
PB-94 32 & 3.45 & 0.55 & 1.02 & 0.88 & 0.23 & 2.14 & 0.20 & 0.12 & 0.03 & 0.35 \\
PB-94 37 & 3.70 & 0.30 & 1.32 & 0.41 & 0.27 & 1.99 & 0.28 & 0.26 & 0.02 & 0.57 \\
PB-94 38 & 3.53 & 0.47 & 0.86 & 0.87 & 0.34 & 2.07 & 0.21 & 0.29 & 0.05 & 0.55 \\
\hline
\end{tabular}

with sandstones and basic rocks which crop out over $\sim 100 \mathrm{~km}$ from the San Vicente Cape (Portugal) to the Huelva Province (Spain). The XRD and TEM data show that the general prograde trend is clearly defined by mineral assemblages, Kübler index (KI) and illite-thickness data in metapelites (Abad et al., 2001, 2002) and by mineral assemblages in metabasites (Munha, 1983). Grades range from anchizone to epizone. Median illite thickness values range from $400 \AA$ in the anchizonal samples to thousands of angstroms in the epizonal samples of the Pulo do Lobo Unit. Smectite was recognized in the Pulo do Lobo samples by XRD (Abad et al., 2001, 2002). The coherence of (001) orders in the $<2 \mu \mathrm{m}$ fractions indicates that smectite is free of illite mixed layers.

Figure 1a shows a BSE image corresponding to the highest-grade epizonal sample. The image area is almost entirely occupied by packets of smectite and muscovite which are subparallel with sharp boundaries, and oriented parallel to slaty cleavage, but not bedding. Muscovite and smectite were identified through qualitative SEM-EDS analysis and by TEM data (Table 2, Fig. 1b).

Transmission electron microscopy images of similar areas (e.g. Fig. 1b) show smectite and muscovite as parallel packets. Smectite displays typical wavy lattice fringes, whereas the muscovite has a typical mottled contrast superimposed on straight, defect-free fringes defining packets with thickness $>100 \mathrm{~nm}$. The muscovite gives characteristic SAED patterns reflecting well ordered $2 M$ polytypism. Analytical electron microscopy (AEM) analyses of some smectite packets indicate significant $\mathrm{Mg}$ and $\mathrm{Fe}$, caused by contamination by layers of chlorite. The amounts of $\mathrm{Mg}$ and $\mathrm{Fe}$ vary (Fig. 2), but the analyses with the smallest values confirm that smectite is dioctahedral, with only typically small amounts of these elements (Table 2). Corrensite in packets parallel with muscovite occur associated with relict chlorite, thin kaolinite packets and irregular goethite domains.

Kaolinite occurs in many samples from the upper anchizonal to epizonal part of this sequence (Abad et al., 2001), as coarse grains in stacks with muscovite or as fine grains in the matrix (Fig. 3). Lateral transitions from 10 to $7 \AA$ layers were observed. I-S layers (20 ̊ spacing) were imaged within the kaolinite and muscovite stacks. Some of the kaolinite cross-cuts the packets of mica, implying that it formed subsequent to the peak metamorphism when muscovite formed.

The common occurrences of smectite and kaolinite are inconsistent with the prograde sequence as determined by KI, muscovite crystallite thickness and mineral assemblages of interbedded metabasites, which include actinolite (Abad et al., 2001). Observations of the Pulo do Lobo samples collectively imply that they were metamorphosed at greenschist conditions, with production of large separate packets of muscovite and chlorite in subparallel cleavage orientation. These samples were subsequently affected by pervasive fluids at

FIG. 1. (facing page) (a) BSE image of sample PB-94, from the Pulo do Lobo Unit, showing textural relations between smectite $(\mathrm{sm})$ and muscovite $(\mathrm{mic})$. The average orientation of subparallel packets is approximately parallel to slaty cleavage. (b) TEM lattice-fringe image of a portion of the area imaged in Fig. 1a. Separate packets of smectite (sm) and muscovite (mic) have continuous, sharp (001) boundaries. 


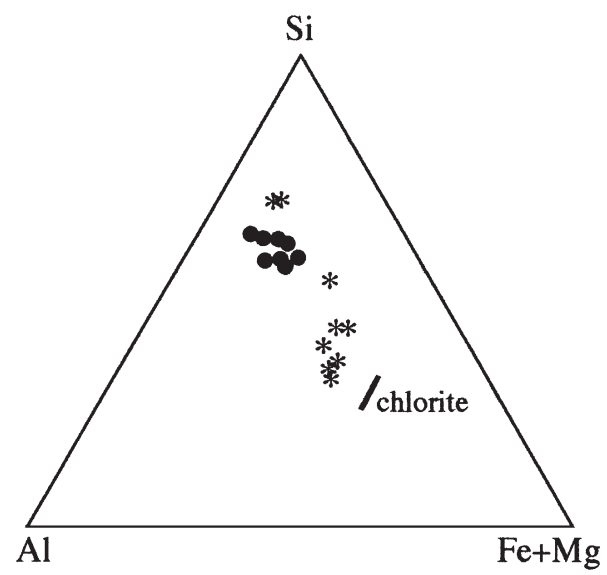

Fig. 2. Triangular plot showing chemical trend $(*)$ of smectite-rich areas analysed in sample $\mathrm{P} \beta-94$ (see Fig. 1). Black dots $(\bullet)$ represent the smectite analyses presented in Table 2. much lower temperatures on a regional scale, resulting in replacement of chlorite by smectite (Fig. 2). Open-system behaviour is clearly demonstrated by the loss of major amounts of $\mathrm{Fe}$ and $\mathrm{Mg}$, and gain in $\mathrm{Si}$.

\section{Palaeozoic of the Iberian range (Pz.I.R.)}

The Iberian range consists of up to $8000 \mathrm{~m}$ of Precambrian and Palaeozoic sediments discordantly overlain by Permian, Triassic and Tertiary sediments. On the basis of XRD, SEM, electron microprobe (EMPA) and TEM data, Bauluz et al. (1995, 1998, 2000) and Bauluz (1997) concluded that Palaeozoic metapelites, pelites and sandstones are composed of detrital quartz and micas (muscovite and phengite) and minor feldspars and chlorite, whereas the fine-grained matrix contains interstratified I-S or illite and subordinate amounts of white mica, chlorite and kaolinite. The samples belong to a prograde sequence ranging from

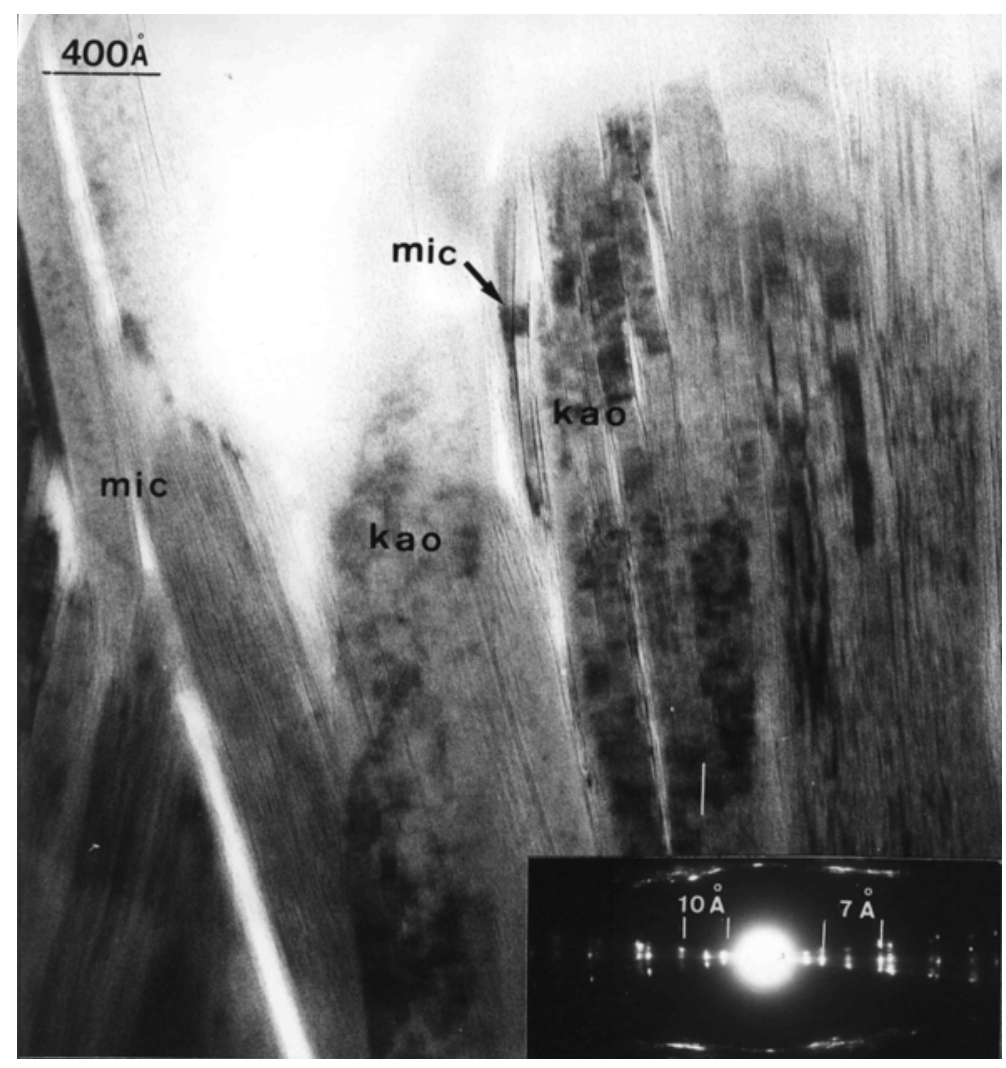

FIG. 3. Lattice-fringe image showing mica (mic) packets partially altered to kaolinite (kao) in sample Pc-9 (South Portuguese Zone). 
diagenesis to anchizone. Grade was determined from mineral assemblages, rock textures, illite polytypism, KI and illite-crystallite thickness. The TEM data show progressive illitization in the finegrained matrix of diagenetic pelites from $(\mathrm{R}=1)$ I-S to illite, whereas the anchizonal metapelites consist of larger packets of well crystallized muscovite with SAED patterns corresponding to a two-layer polytype.

Although the general trend in the diageneticmetamorphic evolution is clear in the Iberian Range, as described by both XRD and TEM methods, we observed I-S phases and kaolinite in some samples, minerals which are inconsistent with the grade. Figure 4a shows a lattice-fringe image of anchizonal mica forming straight $10 \AA$ layers and displaying the typical mottled appearance of mica. The lower area of the crystal has been partially replaced by I-S. The alternating contrast in fringes implies that the I-S interstratification is complex, varying from R1 to R5 types. The image shows lens-shaped areas (white arrows) within the mica which are inferred to represent the nascent alteration to I-S. Occasionally packets of kaolinite within muscovite have also been described and these are considered to be additional evidence for low-temperature alteration subsequent to prograde evolution. On the other hand, Fig. $4 \mathrm{~b}$ shows textural evidence of the phyllosilicate alteration which takes place in the Pz.I.R. Such TEM images display mica crystals which are split and separated into different packets due to the retrograde alteration processes.
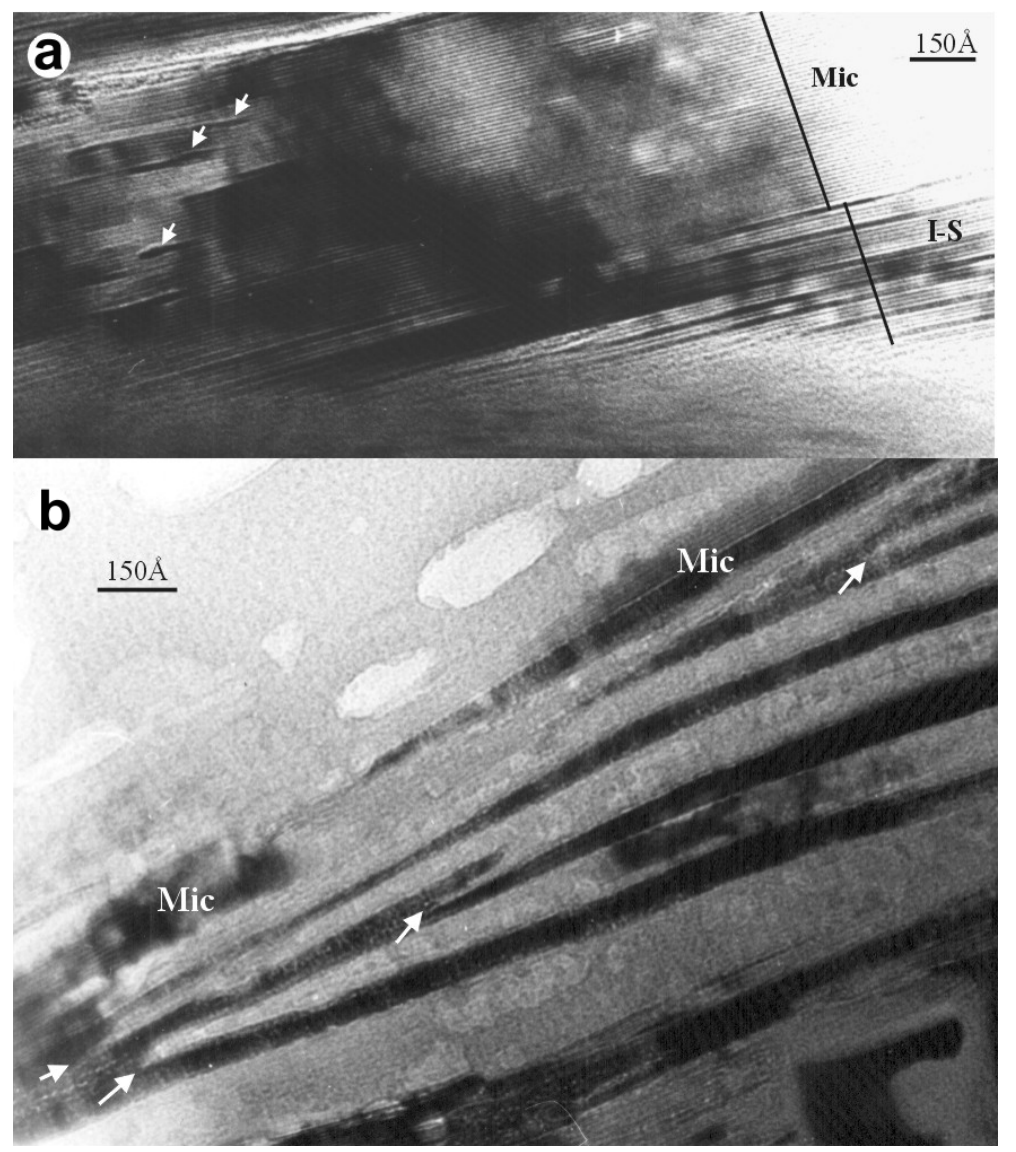

FIG. 4. (a) Lattice-fringe image corresponding to an anchizonal mica (Mic) from the Palaeozoic of the Iberian Range (Spain), formed by straight $10 \AA$ layers, with the typical mottled appearance of mica, being replaced by I-S phases. White arrows are inferred to represent the nascent alteration to I-S. (b) TEM image showing split of mica crystals into several packets. 


\section{Basque-Cantabrian Basin (B.C.B.)}

The Basque-Cantabrian Basin consists of up to $8000 \mathrm{~m}$ of pelites, psammites and carbonates. Aróstegui et al. (1991) found that diagenetic grade increased from south to north, corresponding to increasing sedimentary age and burial depth, with a complete sequence of evolution of smectite through illite, with R1 and R3 I-S as transitional products. Even though there was normal regional prograde evolution (Nieto et al., 1996), samples having R1 I-S and 'unusually' high KI values were found sandwiched between strata within which I-S is of the R3 type (Aróstegui et al., 1993). Such samples are incompatible with normal prograde diagenesis.

Figure 5 is a lattice-fringe image of sample CG-47 from $3000 \mathrm{~m}$ depth showing thick packets of homogeneous mica which give SAED patterns and EDS analyses typical of illite. The central area of Fig. 5 shows wavy layers subparallel to illite layers. The alternating fringe contrast implies that it is I-S largely of the R1 type, but with some R2 sequences. The SAED pattern displays strong, diffuse 001 reflections, but with diffuse and ill-defined non-001 reflections reflecting $1 M_{\mathrm{d}}$ stacking typical of I-S.

\section{Bükkium, northeast Hungary}

The Palaeozoic and Mesozoic formations of the Bükkium (Bükk, Uppony and Szendrö Mountains in NE Hungary) underwent low to low-medium pressure Alpine regional metamorphism ranging from upper diagenesis to epizone, as determined by phyllosilicate "crystallinity" indices of metasedi- ments and mineral assemblages of metabasites (Árkai, 1983, 1991; Downes et al., 1990; Árkai et al., 1995; Árkai \& Sadek Ghabrial, 1997). In the eastern Bükk Parautochthon, metamorphism corresponded to the pumpellyite-actinolite facies in Carnian metabasalts, to the chlorite-zone greenschist facies in Ladinian metatuffs, and to upper anchizone and epizone in intercalated metaclastics (for mineralogical characterization, see Árkai et al., 2000 and Mata et al., 2001).

Smectitic and I-S layers were detected in rims of $>500 \mathrm{~nm}$ thick muscovite crystals of metapelites and meta-andesites from the eastern Bükk Mountains. Large muscovite crystals, which formed during epizonal metamorphism, contain smectite layers which are split and separated (Fig. 6). In addition, $24 \AA$ chlorite-smectite (corrensite) mixed-layers (Fig. 7) and $7 \AA$ berthierine layers are interstratified within large chlorite crystals of upper anchizonal or epizonal grade in metapelites, metabasalts and meta-andesite tuffs.

Alpine regionally metamorphosed Palaeozoic formations of the Uppony Mountains epizonal slate and metasandstone intercalated with metabasalt were obtained from a borehole. Large $(\sim 500 \AA$ thick) stacks of corrensitic and smectite layers also occur within chlorite grains in metabasalt and metaclastic rocks (Fig. 8a). Smectite layers occur within large muscovite crystals in metaclastic rocks. Formation of berthierine at the rims of chlorite crystals, i.e. lateral transitions of one $14 \AA$ layer to two $7 \AA$ layers, are frequent in metabasalts. Figure $8 \mathrm{~b}$ shows an image of berthierine and a thick chlorite crystal where transition from chlorite to berthierine can be seen.

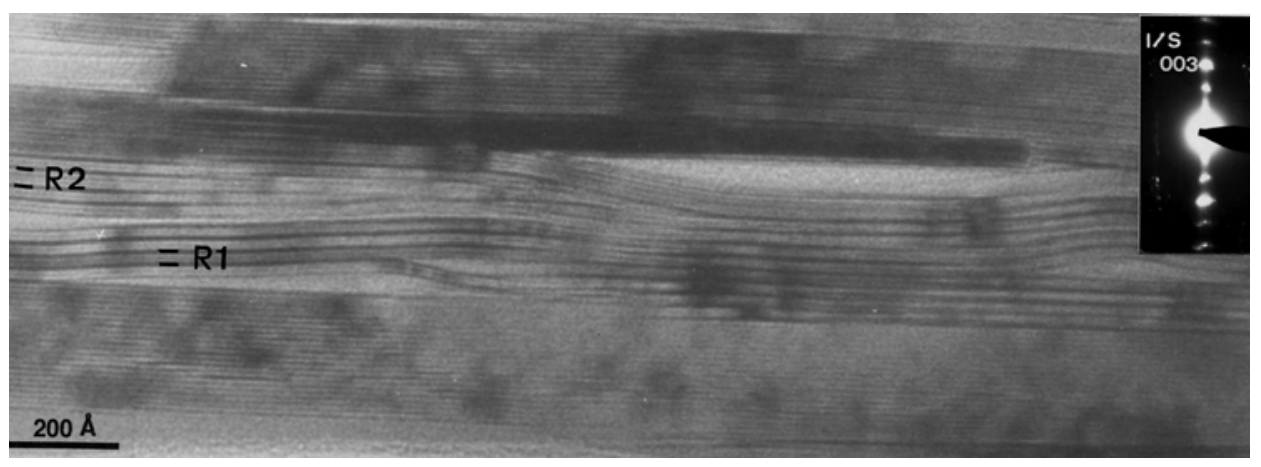

FIG. 5. TEM lattice-fringe image of sample from the Basque-Cantabrian Basin, showing packets of illite of diagenetic origin and packets of R1 and R2 I-S, with typical alternating contrast for illite- and smectite-like layers. I-S is inferred to have replaced illite. 


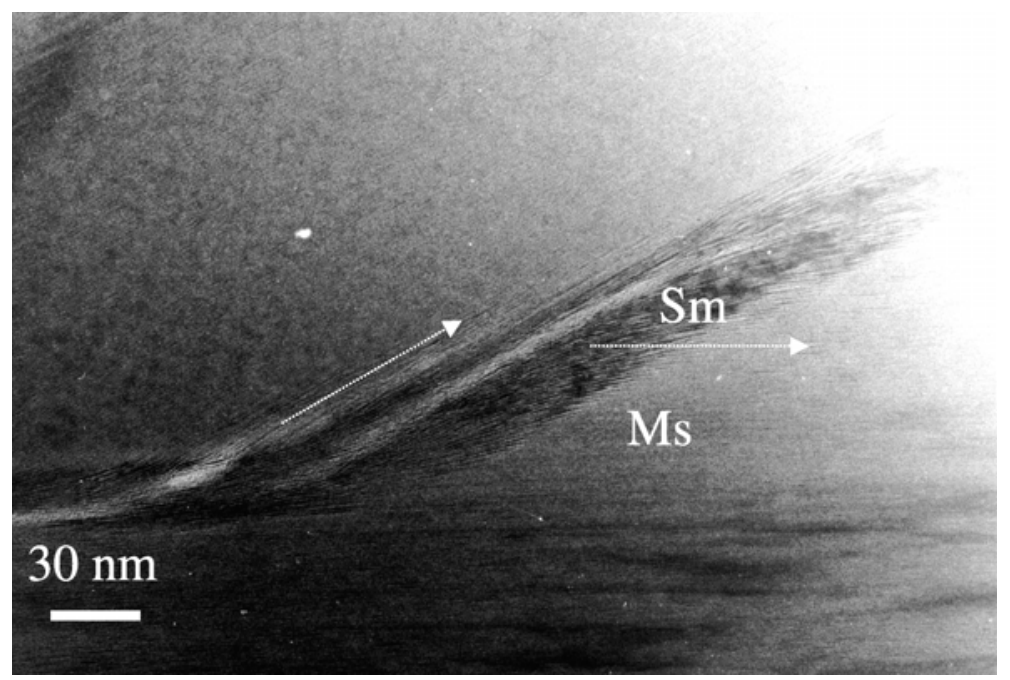

FIG. 6. TEM lattice-fringe image of a $2 M$ muscovite (Ms) crystal from the Eastern Bükk Mountains (Hungary), showing alteration to smectite $(\mathrm{Sm})$ along layers (white arrows).

\section{DISCUSSION}

The data from the present work and from sequences documented previously (Table 1 and introductory text) demonstrate clearly that material typical of low-temperature assemblages replaced chlorite, illite and muscovite of grades ranging from diagenesis to greenschist facies, on a regional scale. These processes affect fine-clastic metasedimentary and metavolcanic rocks from a wide

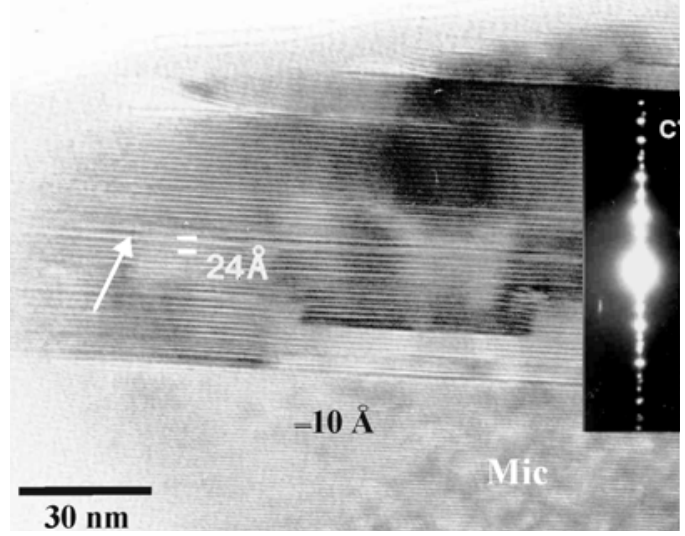

FIG. 7. TEM lattice-fringe image of muscovite (Mic) and chlorite from pumpellyite-actinolite-facies metabasalts from the Eastern Bükk Mountains (Hungary). Corrensitic units (white arrow) occur within thick chlorite crystals. variety of geological settings and ages (Table 1). Phyllosilicate retrogression may produce mineral grains large enough to be characterized by optical microscopy (Nevado-Filabride Complex) or BSE imaging (South Portuguese Zone), but in most cases they may be identified only at the nanometer scale (e.g. Bükkium, Iberian Range).

The reactions were typical of those where one phyllosilicate replaces another, with packets of reaction products being parallel or subparallel to reactants. Major composition and/or structure differences clearly imply that reactions proceeded by dissolution and crystallization as mediated by fluids under low-temperature, open-system conditions. Such alteration is analogous to retrograde metamorphism, although not necessarily during cooling from regional peak-metamorphic conditions. It may occur in separate, subsequent events where fluids were activated by independent tectonic events or other geological processes. The conditions of replacement occur at temperatures normally associated with diagenesis, well below epizonal conditions, as implied by the presence of smectite, kaolinite, illite-smectite, chlorite-smectite and berthierine as reaction products. We therefore refer to the process as "retrograde diagenesis".

The examples of retrograde diagenesis documented above through TEM data were detected because they occurred within regionally-developed prograde sequences where prograde minerals were 

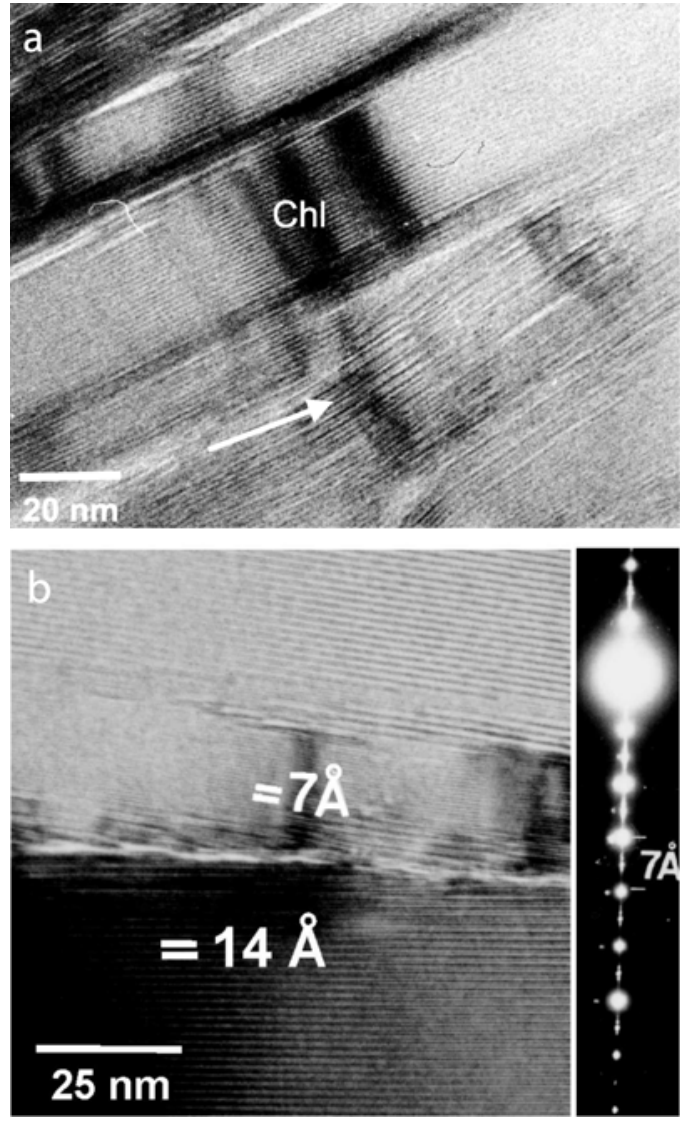

FIG. 8. (a) TEM lattice-fringe image of chlorite (14 $\AA$ ) crystals from a sandstone of borehole Dt-8-207.8 from the Uppony Mountains (Hungary). Corrensitic units (white arrow) can be observed with epizonal chlorite crystals. (b) TEM lattice-fringe image of chlorite (14 $\AA$ ) crystals from a metabasalt of borehole Dt8129.5 from the Uppony Mountains (Hungary). Berthierine $(7 \AA)$ packets occur between and in the rims of chlorite crystals.

sufficiently preserved to allow peak diagenetic/ metamorphic grade to be determined. Their interpretation in the normal prograde context would probably have produced incorrect geological interpretations. The collective examples demonstrate that caution should be used in assuming prograde relations in all cases, especially where metasediments are of significant age.

S. Hillier (pers. comm.) has suggested that the presence of pure smectite as detected by powder XRD may indicate that such material has formed through retrograde diagenesis. He noted that pure smectite, as opposed to mixed-layered I-S $(<50 \%$ I) is not common, except in bentonites, because in most geological occurrences, at least some degree of low-grade metamorphism has caused the formation of illite layers. The occurrences described in this study, or in other work, were indeed shown not to include any such mixed-layered I-S $(<50 \%$ I), although the amount of smectite or I-S may be so small, as in the Hungarian samples, to be detected by XRD. On the other hand, ordered mixed-layered I-S, dominated by R1 sequences, was detected in several studies. Stixrude and Peacor (2002) implied that smectite-rich I-S is metastable relative to pure smectite or R1 I-S, as consistent with a lack of such phases in the retrograde diagenesis environment, although such material forms in prograde sequences. More studies are required to verify that mixed-layered I-S $(<50 \%$ I) does not form by retrograde diagenesis. Nevertheless, the available data do indicate that the presence of pure smectite in rocks other than bentonites, as detected by XRD, serves as an indicator of the possibility that retrograde diagenesis occurred.

Reactions occur on a regional basis via orogenic fluids, aided perhaps by tectonic stress-induced strain. The occurrence of tectonically driven, regional fluid flow which results in low-temperature reactions has been amply demonstrated, e.g. during the Alleghanian orogeny in the central Appalachians (Miller \& Kent, 1988; Bethke \& Marshak, 1990). The changes were subtle, being indirectly detected only by means of palaeomagnetic or geochronological studies. Katz et al. (2000) demonstrated a relation between changes in clay mineralogy and chemical remagnetization in diagenetic environments, and Tournier et al. (1999) studied the relation between K-Ar ages of diagenetic illite and the remagnetization of enclosing sediments. In the sections studied by the authors cited, field evidence of the effects of fluids was lacking. Nevertheless, the areas were subjected to tectonic stress that caused regional flow of fluids which mediated low-temperature reactions (Oliver, 1986). Phyllosilicate retrogression in the Eastern Bükk Mountains, for example, was attributed to widespread mylonite formation at $79 \pm 3 \mathrm{Ma}$, subsequent to peak metamorphism at $120 \mathrm{Ma}$ (Árkai et al., 1995). By contrast, in the Uppony Palaeozoic the retrograde effects described above were related to migration of hydrothermal fluids subsequent to regional metamorphism (Árkai et al., 1981; Polgári \& Fórizs, 1996). 
There is a number of possible reasons why more examples of retrograde diagenesis have not been yet identified. One is simply that the range of low-grade metamorphism is limited relative to the full range of regional metamorphism, and superposition of even lower-grade events is less probable. Another relates to the metastability of authigenic clays like illite and smectite (Jiang et al., 1990b), wherein reactions proceed in a prograde sense towards the thermodynamically stable assemblages. Thus, only when conditions are radically altered, can introduction of high water/rock ratios under open-system conditions result in the formation of metastable smectite-rich materials as consistent with the Ostwald step rule. Lastly, only where subtle textural relations can be directly observed, can sequences of formation be determined unambiguously. Where chlorite but not muscovite has been replaced by smectite, for example, XRD patterns could be interpreted to consist of detrital mica and authigenic smectite.

\section{CONCLUSIONS}

Identification of smectite or I-S in fine-grained rocks is usually made by $\mathrm{XRD}$, without regard to textural relations. The origin and timing of such phases may therefore be incorrectly interpreted within a normal prograde context. This study, based on examples from a variety of geological settings, both new and from the literature, demonstrates that 'retrograde reactions' may be common on a regional scale. Caution should therefore be used in assuming prograde reactions. Only when textural relations can be observed directly can sequences of formation be determined unambiguously. Nevertheless, the presence of characteristic low-temperature minerals, e.g. pure smectite, together with mineral associations and XRD parameters typical of low- or very-low-grade metamorphism should be interpreted as characteristic of retrograde diagenetic events. In older metasediments, in particular, 'retrograde reactions' should be considered as due to possible post diagenetic/metamorphic tectonic influence.

\section{ACKNOWLEDGMENTS}

Financial support was provided to P.Á. by grant T-035050 from the Hungarian National Research Fund (OTKA, Budapest), to DRP through NSF grant EAR-9814391, and to FN by the Spanish Education Ministry (BTE2003-07867-C02-01) and Junta de
Andalucia (RNM0179). We are grateful to the reviewers, S. Hillier and M. Rodas, whose helpful reviews led to significant improvements in the manuscript. S. Hillier is acknowledged in particular, for his insights into the significance of the occurrence of pure smectite.

\section{REFERENCES}

Abad I., Mata M.P., Nieto F. \& Velilla N. (2001) The phyllosilicates in diagenetic-metamorphic rocks of the South Portuguese Zone, Southwestern Portugal. The Canadian Mineralogist, 39, 1571-1589.

Abad I., Nieto F. \& Velilla N. (2002) Chemical and textural characterisation of diagenetic to low-grade metamorphic phyllosilicates in turbidite sandstones of the South Portuguese Zone: A comparison between metapelites and sandstones. Schweizerische Mineralogische und Petrographische Mitteilungen, 82, 303-324.

Árkai P. (1983) Very low- and low-grade Alpine regional metamorphism of the Paleozoic and Mesozoic formations of the Bükkium, NE Hungary. Acta Geologica Hungarica, 26, 83-101.

Árkai P. (1991) Chlorite crystallinity: an empirical approach and correlation with illite crystallinity, coal rank and mineral facies as exemplified by Palaeozoic and Mesozoic rocks of Northeast Hungary. Journal of Metamorphic Geology, 9, 723-734.

Árkai P. \& Sadek Ghabrial D. (1997) Chlorite crystallinity as an indicator of metamorphic grade of lowtemperature meta-igneous rocks: a case study from the Bükk Mountains, Northeast Hungary. Clay Minerals, 32, 205-222.

Árkai P., Horváth Z.A. \& Tóth M. (1981) Transitional very low- and low-grade regional metamorphism of the Paleozoic formations, Uppony Mountains, NEHungary: mineral assemblages, illite-crystallinity, $-\mathrm{b}_{\mathrm{o}}$ and vitrinite reflectance data. Acta Geologica Academiae Scientarum Hungaricae, 24, 265-294.

Árkai P., Balogh K. \& Dunkl I. (1995) Timing of lowtemperature metamorphism and cooling of the Paleozoic and Mesozoic formations of the Bükkium, innermost Western Carpathians, Hungary. Geologische Rundschau, 84, 334-344.

Árkai P., Mata M.P., Giorgetti G., Peacor D.R. \& Tóth M. (2000) Comparison of diagenetic and low-grade metamorphic evolution of chlorite in associated metapelites and metabasites: an integrated TEM and XRD study. Journal of Metamorphic Geology, 18, 531-550.

Aróstegui J., Zuluaga M.C., Velasco F., Ortega-Huertas M. \& Nieto F. (1991) Diagenesis of the Central Basque-Cantabrian basin (Iberian Peninsula) based on illite-smectite distribution. Clay Minerals, 26, $535-548$. 
Aróstegui J., Nieto F., Ortega-Huertas M., Velasco F. \& Zuluaga M.C. (1993) Mineralogía de arcillas y grado de diagénesis del Cretácico inferior, en el flanco sur del anticlinorio de Bilbao. Estudios Geológicos, 49, 277-286.

Bauluz B. (1997) Caracterización mineralógica y geoquímica de materiales detríticos precámbricos y paleozoicos de las Cadenas Ibéricas: Evolución post-sedimentaria. $\mathrm{PhD}$ thesis, University of Zaragoza, Spain, 341 pp.

Bauluz B., Mayayo M.J., Fernández-Nieto C. \& González López J.M. (1995) Mineralogy and geochemistry of Devonian detrital rocks from the Iberian Range (Spain). Clay Minerals, 30, 381-394.

Bauluz B., Mayayo M.J. \& González López J.M. (1998) Diagenesis-very low-grade metamorphism of clastic Cambrian and Ordovician sedimentary rocks in the Iberian Range (Spain). Clay Minerals, 33, 373-394.

Bauluz B., Peacor D. \& González López J.M. (2000) Transmission electron microscopy study of illitization in pelites from the Iberian Range, Spain: layerby-layer replacement? Clays and Clay Minerals, $\mathbf{3}$, 374-384.

Bethke C.M. \& Marshak S. (1990) Brine migrations across North America - the plate tectonics of groundwater. Annual Review of Earth and Planetary Sciences, 18, 287-315.

Do Campo M. (1999) Metamorfismo del basamento en la Cordillera Oriental y borde oriental de la Puna. Pp. 41-51 in: Relatorio XIV Congreso Geológico Argentino Geología del Noroeste Argentino (G. González Bonorino, R. Omarini \& J. Viramonte, editors). Universidad de Salta, Argentina.

Do Campo M. \& Nieto F. (2003) Transmission electron microscopy study of very low-grade metamorphic evolution in Neoproterozoic pelites of the Puncoviscana formation (Cordillera Oriental, NW Argentina). Clay Minerals, 38, 459-481.

Downes H., Pantó Gy., Árkai P. \& Thirlwall M.F. (1990) Petrology and geochemistry of Mesozoic igneous rocks, Bükk Mountains, Hungary. Lithos, 24, 201-215.

Jiang W.T., Peacor D.R., Merriman R.J. \& Roberts B. (1990a) Transmission and analytical electron microscopic study of mixed-layer illite/smectite formed as an apparent replacement product of diagenetic illite. Clays and Clay minerals, 38, 449-468.

Jiang W.T., Essene E.J. \& Peacor D.R. (1990b) Transmission electron microscopic study of coexisting pyrophyllite and muscovite: direct evidence for metastability of illite. Clays and Clay Minerals, 38, $225-240$.

Jiang W.T., Peacor D.R. \& Slack J.F. (1992) Microstructures, mixed layering, and polymorphism of chlorite and retrograde berthierine in the Kidd Creek massive sulphide deposit, Ontario. Clays and Clay Minerals, 40, 501-514.
Katz B., Elmore R.D., Engel M.H., Cogoini M. \& Ferry S. (2000) Associations between burial diagenesis of smectite, chemical remagnetization and magnetite authigenesis in the Vocontian Trough of SE France. Journal of Geophysical Research, 105, 851-868.

Mata M.P., Giogetti G., Árkai P. \& Peacor D.R. (2001) Comparison of evolution of trioctahedral chlorite/ berthierine/smectite in coeval metabasites and metapelites from diagenetic to epizonal grades. Clays and Clay Minerals, 49, 318-332.

Mellini M., Nieto F., Álvarez F. \& Gómez-Pugnaire M.T. (1991) Mica-chlorite intermixing and altered chlorite from the Nevado-Filabride micaschists, Southern Spain. European Journal of Mineralogy, 3, 27-38.

Merriman R.J. \& Peacor D.R. (1999) Very low-grade metapelites: mineralogy, microfabrics and measuring reaction progress. Pp. 10-60 in: Low-grade Metamorphism (M. Frey \& D. Robinson, editors). Blackwell Science, Oxford, UK.

Miller J.D. \& Kent D.V. (1988) Regional trends in the timing of Alleghanian remagnetizations in the Appalachians. Geology, 16, 588-591.

Munha J. (1983) Low-Grade Regional Metamorphism in the Iberian Pyrite Belt. Comunicações dos Serviços Geologicos de Portugal, 69, 3-35.

Nieto F. \& Peacor D.R. (1993) Regional retrograde alteration of prograde lower grade hydrated assemblages. Terra Abstracts, 419.

Nieto F., Velilla N., Peacor D.R. \& Ortega Huertas M. (1994) Regional retrograde alteration of sub-greenschist facies chlorite to smectite. Contributions to Mineralogy and Petrology, 115, 243-252.

Nieto F., Ortega-Huertas M., Peacor D.R. \& Aróstegui J. (1996) Evolution of illite/smectite from early diagenesis through incipient metamorphism in sediments of the Basque-Cantabrian basin. Clays and Clay Minerals, 44, 304-323.

Oliver J. (1986) Fluids expelled tectonically from orogenic belts; their role in hydrocarbon migration and other geologic phenomena. Geology, 14, 99-102.

Polgári M. \& Fórizs I. (1996) Distribution of Mn in carbonates from the Uppony Mts., NE-Hungary. Geologica Carpathica, 47, 215-225.

Stixrude L. \& Peacor D.R. (2002) First-principles study of illite-smectite and implications for clay mineral systems. Nature, 420, 165-168.

Tournier B., Liewig N., Edel. J.B. \& Montigny R. (1999) Concordance d'âges de réaimantations: exemple des grès triasiques d'Alsace. Comptes Rendus de l'Academie des Sciences, Paris, 329, $7-13$.

Zhao G., Peacor D.R. \& McDowell D.S. (1999) Retrograde diagenesis of clay minerals in the Precambrian Freda sandstone, Wisconsin. Clays and Clay Minerals, 47, 119-130. 